\title{
Immunohistochemical Expression of Leptin in Mammary Carcinoma
}

\author{
YASMINE F. ELESAWY, M.D.; RASHA M. RAMADAN, M.D. and SAMAR I. ISMAIL AMER, M.D.
}

The Department of Pathology, Faculty of Medicine, Cairo University, Cairo, Egypt

\begin{abstract}
Background: Leptin is a multifunctional adipose regulatory peptide that has various actions in carcinogenesis. Mammary carcinoma is one of the leading cancers in the world with tempted aspects to explore new prognostic factors.

Aim of Study: We attempted to leptin expression in mammary carcinoma and its clinicopathological correlation.

Material and Methods: Thirty-five cases of breast carcinomas were studied for correlating leptin immunohistochemical expression with other available parameters.

Results: The included cases' mean age is 57 years \pm SD 11.7. The majority of cases were invasive duct carcinoma. As regards clinical pathological stages, stage IA (48.6\%), stage IB (14.3\%), stage IIA (14.3\%), stage IIIA (2.9\%), stage IIII $(14.3 \%)$, and finally stage IIIC $(5.7 \%)$. Leptin immunostain was positive in $60 \%$ of studied mammary carcinoma cases and negative in $40 \%$. Five cases of peritumoral fibrocystic disease were studied; all showed leptin positivity in ductal cells. Correlating leptin immunohistochemistry results with other findings, we found that significant relationship was found between leptin staining and mammary carcinoma histopathological type. Most invasive duct carcinoma (NST) showed positive leptin immunostaining $(67.9 \%)$. On the other hand, most cases of the other types (lobular and mixed carcinomas) showed negative staining (71.4\%) ( $p$-value 0.027). Leptin immunostaing had insignificant correlation to $\mathrm{T}$ stage, grade, tumor lymphovascular emboli and perineural infiltration. As regarding tumor lymph nodal metastasis, most of cases without nodal metastasis (N0) were leptin-positive (76.5\%) with significant $p$-value of 0.025 . A significant relationship was detected between leptin immunostaining and clinicopathologic staging as well as molecular subtype. Estrogen-positive cases significantly correlate with leptin, with $p$-value of 0.0001 . This also was observed with progesterone positivity, with $p$ value of 0.002 . No significant relationship was found between leptin and Her-2 as well as Ki-67.

Conclusion: Leptin immunostain can be of an extreme help in mammary carcinoma prognosis.
\end{abstract}

Key Words: Leptin-Breast carcinomaImmunohistochemistry.

Correspondence to: Dr. Yasmine F. Elesawy, E-Mail: yasmine_esawy@kasralainy.edu.eg

\section{Introduction}

BREAST cancer is a worldwide notorious health problem that ranks the first in females' cancercaused mortality. According to GLOBOCAN 2018 world incidence, it accounts for $24.2 \%$ of cancer cases and $15 \%$ of cancer death [1]. In Egypt; according to GLOBOCAN regional cancer registry 2018; it accounted for $35.1 \%$ of all new cancer cases and the second in cancer-caused mortality in females [1]. Risk factors for breast cancers are many, some are constitutional and about $20 \%$ is modifiable, including overweight and obesity $[2,3]$.

Obesity; has a distressing incidence worldwide, according to WHO fact sheets; about 2 billion adults are considered as overweight and about 600 million people are categorized as obese worldwide [ 4]. Overweight and obesity are known to be risk factors for different malignancies including breast cancer in postmenopausal females $[\mathbf{5 , 6 ]}$ who will have a $12 \%$ higher risk for each $5 \mathrm{~kg} / \mathrm{m}^{2}$ increase in Body Mass Index (BMI) [7]. They are also condemned for the more dismal prognosis, which is independent of the menopausal status [8,9].

The role of obesity in breast carcinogenesis is complex, it involves dysregulated production of adipokines, exaggerated steroid hormones action, altered response to insulin, Insulin-like Growth Factor (IGF) I, and a sustained chronic local inflammatory response [10]. Adipokines are a family of energy regulating peptides that include leptin and adiponectin. It is mainly produced by adipose tissue. Adiposity is associated with increased secretion of leptin and decreased adiponectin levels. This disturbed ratio was proved to increase the risk of breast cancer [11,12]. Adiponectin is known to have an anti-neoplastic effect through inhibiting cell growth, invasion, and migration and it also promotes apoptosis $[\mathbf{1 3 , 1 4}]$. Leptin is a multifunctional adipo-regulatory peptide. It also con- 
tributes to fetal development, sex maturation, lactation, hematopoiesis, and immune responses [15-19].

The biological actions of leptin are mediated through the leptin receptor that activates several intracellular signaling pathways [20,21]. Higher serum leptin and overexpression of its receptors in breast cancer are correlated with hormone receptor, tumor size, and higher tumor grade [22,23]. Leptin is considered as a pleuri-potent procarcinogenic factor that promotes all stages of breast cancer development. It contributes directly to expanding malignant cell mass by promoting epithelial cell proliferation, and transformation through amplification of ER signaling [24,25] and trans-activating HER2 [26] and it inhibits apoptosis through a Bcl-2-dependent mechanism [27]. The indirect effect is exerted on the tumor microenvironment through its angiogenic capability [28], and pro-inflammatory effect [29].

Leptin can induce several signaling pathways that are involved in breast carcinogenesis like JAK/STAT which induces cyclin D1 expression [ 30], and up-regulating human Telomerase Reverse Transcriptase (hTERT) activity [31], PI3K/AKT that controls specific signals on the insulin receptor substrate [32] enhancing the cellular proliferation, modifying the expression of the key regulators of Epithelial-Mesenchymal Transition (EMT) facilitating invasion and metastasis [33]. It is anticipated to up-regulate Acetyl-CoA Acetyltransferase 2 ( ACAT2) concerned with the proliferation, migration, and invasion of cancer cells [34] and regulating epithelial-mesenchymal transition mediated by IL-8 [35].

Notably; leptin can modify the main hormonal influencers of breast cancer; through ERK signaling; it induces stromal aromatase enzyme, thereby increasing estrogen level in breast tissue [36] and also stimulates the estrogen receptor alpha (ER/x) [ 37,38]. It also augments the Epidermal Growth Factor Receptor (EGFR) signaling pathways through IGF-1 signaling [39]. A dual beneficial relationship exists between HER2 and leptin as HER2 induces the expression of leptin in mammary cancer cells [40] and leptin pays back through transactivating HER 2 mediated by the activation of the EGFR and JAK2, resulting in overexpression of HER2 in mammary cancer cells $[\mathbf{4 1 , 4 2 ]}$.

Solid malignant tumors are often hypoxic with the production of Hypoxia-Inducible Factor (HIF1) that induces leptin expression in adipocytes and fibroblasts $[\mathbf{4 3}, \mathbf{4 4}]$. Leptin exerts a pro-angiogenic effect through MAPK/ERK 1/2, p38, and JNK signaling pathways. It facilitates angiogenesis either alone or combined with Vascular Endothelial Growth Factor (VEGF) and Fibroblast Growth Factor (FGF-2) [45]. It also can increase the levels and promote the action of Matrix Metalloproteinases (MMPs) 2 and 9; involved in angiogenesis $[46,47]$.

Leptin can trigger a pro-inflammatory microenvironment at the tumor bed, known as Crownlike Structures (CLS). It is formed of activated macrophages and a plethora of inflammatory mediators (e.g. TNF- $(x$ and IL-6) [48] that activate the aromatase enzyme $[\mathbf{4 9 , 5 0 ]}$, stimulate angiogenesis, promote metastatic potential, facilitate the evasion of the immune system, and influence the response to therapy $[\mathbf{5 1 , 5 2 ]}$.

Cancer Stem Cells (CSCs) have a fundamental role in breast carcinogenesis. They show selective expression of the leptin receptor and an increased response to its action [53]. Many studies have shed light on the role of the leptin signaling pathways ( i.e., Notch, Wnt, mTOR, STAT3, HER2/Erb, and IGF pathways) and its transcription factors (i.e., NF_B and hypoxia-inducible factor) in influencing CSC activity [54-56].

A growing list of evidence supports the antagonizing role of leptin during the treatment stage; It increases the resistance to chemotherapy by the expression of enzymes essential for acid (oxidation pathways [57], through JAK/STAT signaling pathway, it also increases the activity of HER2, making the malignant cells less sensitive to monoclonal trastuzumab treatments [58]. Moreover; it stabilizes the Estrogen Receptor alpha ( ERa), sustaining ERa-dependent transcription in malignant cells despite the presence of antiestrogens [59].

Aim of work: To study leptin immunostain in breast carcinoma and to correlate it with the available clinicopathological factors.

\section{Material and Methods}

This retrospective institutional study was conducted by collecting data and tissue blocks from Kasr Al-Ainy Hospital, Cairo University. Pathologic records of patients who underwent mastectomy were assessed. The study was approved by the Ethics Committee of the Faculty of Medicine, Cairo University for use of patients' samples for research purposes.

We retrieved 35 cases of breast carcinomas during the interval between 2018 and 2019. Tu- 
moral paraffin-embedded cell blocks were collected. Hematoxylin and Eosin (H \& E) slides were reviewed. Selecting the tumor block with representable preserved invasive viable tissue was done.

Serial sections (4-gm) were prepared from the tumor blocks and mounted on adhesive-coated glass slides for Estrogen (ER), Progesterone (PR), HER2/neu, Ki67 and leptin staining. Commercially available ER (1: 50; Dako), PR (1: 10; Dako), HER2/neu (1: 10; Dako), and Ki67 (1: 300, Cat. \#RB-9043-P; Lab Vision, Thermo Fisher Scientific, Fremont, USA) were used as primary antibodies. Leptin primary antibody used is a rabbit antihuman polyclonal anti-leptin antibody (Chongqing Biospes Co, Jiangbei District, Chongqing, China) at 1:100 dilution. Immunohistochemistry autostainer ( BenchMark ULTRA, Ventana, Arizona, USA) was used for immunohistochemistry staining.

Briefly, 5-gm-thick tissue sections were deparaffinized in xylene and rehydrated in graded alcohol, and subsequently microwave-treated in sodium citrate buffer ( $\mathrm{pH}$ 6.0) twice. Endogenous peroxidase activity was quenched with $3 \% \mathrm{H}_{2} \mathrm{O} 2$ for $15 \mathrm{~min}$, followed by washing with Tris-buffered saline. The sections were then incubated with diluted primary antibody (NBP2-22204; Novus Biologicals, Littleton, USA). Thereafter, the sections were refrigerated at $4^{\circ} \mathrm{C}$ overnight in a humid closed chamber. The sections were again washed in Tris-buffered saline and incubated with avidinbiotin-peroxidase system (Dako, Dako Corporation, Carpinteria, CA, USA) for 30min. The diaminobenzidine was used as a chromogen and hematoxylin as a counterstain.

For leptin stain, internal positive control of mammary adipose tissue was included. As for estrogen and progesterone, surrounding normal breast tissue act as an internal positive control; as for HER2 and Ki67, a known overexpressing breast carcinoma was used. Negative control is done by omitting the primary antibodies. The immunostained entire slide had been evaluated and subsequently scored by light microscopy; provided that the staining did not represent background or artifact. Hematoxylin and eosin stained sections were evaluated by Leica light microscopy along with the prepared immunohistochemically stained slides.

Histologic nuclear grading of the surgical specimens was performed according to the BloomRichardson's criteria [60]. A standard histopathologic examination was done that included determining the type of cancer and the pathologic tumor stage, which were assessed according to the criteria established by the 8th edition AJCC staging manual [61].

A cutoff value of $1 \%$ for the stained nuclei was used to define ER and PR positivity. Evaluation of the percentage of tumor nuclei stained and intensity of staining was done, classifying it to strong and weak expressions. Membranous staining for HER2 with strong complete staining in $10 \%$ of the tumor cells was regarded as HER2 overexpression. Samples with scores $3+$ were regarded as positive for HER-2/neu. The Ki-67 labeling index was expressed as a percentage and was graded as "high" if the number of positive cells was >_20\% [61].

The available data were collected and tabulated; including patient's age, gender and history of neoadjuvant chemotherapy treatment, as well as pathological factors as tumor size, tumor grade, lymph node metastasis, tumor perineural/lymphovascular invasion, presence of in situ component and surrounding fibrocystic disease. We classified cases into its appropriate stage and molecular subtype.

A five high power field was used for leptin evaluation. The expression of leptin was localized to the cytoplasm. The evaluation was assessed by semi-quantitative method. Immunohistochemical leptin staining evaluation was done by scoring leptin stain intensity and percentage of stained tumor cells. Staining was subjectively scored to tiered system (0- Nil, 1 - Weak focal $<10 \%$, 2Moderate focal $11-50 \%$, 3- Marked diffuse $>50 \%$ ). For the statistical purposes, the negative/weak focal staining was considered negative; while moderate/strong was considered positive [62].

Data were analyzed using IBM SPSS advanced statistics (Statistical Package for Social Sciences), version 24 (SPSS Inc., Chicago, IL, USA). Numerical data were described as mean and standard deviation or median and range. Categorical data were described as numbers and percentages. Data were explored for normality using KolmogrovSmirnov test and Shapiro-Wilk test. Comparisons between two groups for numeric variables were done using the Student's $t$-test w. Comparisons between categorical variables were performed using the chi square test and fisher exact test as appropriate. A $p$-value less than or equal to 0.05 were considered statistically significant. All tests were two tailed.

\section{Results}

Leptin is an important cytokine for lipid metabolism and energy balance, with related postula- 
tion to the development of breast cancer. However, the relationship between leptin and breast cancer prognosis is still controverted. In this study, we investigated leptin immunohistochemistry in 35 cases of mammary carcinomas, tried to find relations with hormonal and proliferation indices as well as tumor invasiveness and staging.

The included cases' mean age is 57 years \pm SD 11.7 , with range $30-78$ years and median of 55 . Only female gender was found in studied cases ( $100 \%$ ). Regarding the size of breast tumors, the mean size is $3.6 \mathrm{~cm} \pm \mathrm{SD} 2.1$, with range 1.2 to $10.5 \mathrm{~cm}$ and median of $3 \mathrm{~cm}$.

Only four of the studied cases have history of neoadjuvant chemotherapy (11.4\%). Regarding the T stage; 7 cases were T1 $(20.0 \%), 22$ cases were T2 $(62.9 \%)$ and 6 cases were T3 $(17.1 \%)$. The majority of cases (28 cases, $80.0 \%$ ) were invasive duct carcinoma (NST). The rest of cases exhibit lobular carcinoma type (4 cases, $11.4 \%$ ), invasive mixed ductal and lobular carcinoma (2 cases, $5.7 \%$ ) and only one case of invasive papillary carcinoma $(2.9 \%)$. Seventeen cases showed in situ ductal carcinoma $(48.6 \%)$. Nine cases showed evidence of tumor lympho-vascular invasion (25.7\%); while five cases showed perineural tumor infiltration (14.3\%). As regards lymph nodes metastasis, eighteen cases showed positive lymph nodal metastasis $(51.4 \%)$. Nodal staging is as follows; N0: 17 cases (48.6\%), N1: 10 cases $(28.6 \%), \mathrm{N} 2: 3$ cases $(9.6 \%)$, and N3: 5 cases ( $14.3 \%$ ). Concentrating on tumor grading, ten cases were grade I (28.6\%); while most cases were grade II (25 cases, $71.4 \%$ ). No case showed grade III.

By classifying cases into clinical pathological stages, we find 17 cases (48.6\%) were stage IA, 5 cases were of stage IB (14.3\%). Total cases of stage I is 22 cases $(62.9 \%)$. Five cases were of stage IIA $(14.3 \%)$. Only one case was of stage IIIA ( $2.9 \%)$, five cases were of stage IIIB $(14.3 \%)$, and finally 2 cases were of stage IIIC $(5.7 \%)$. Total cases of stage III was 8 cases $(22.9 \%)$.

As regards immnuno staining, all cases were stained with estrogen, progesterone, Her-2, Ki67 and leptin. Estrogen-positive cases were 26 ( $74.3 \%$ ), while 9 cases were negative $(25.7 \%)$. Eighteen cases showed strong estrogen labeling intensity (51.4\%), while eight showed a weak one ( $22.9 \%$ ). Progesterone-positive cases were 20 cases ( $57.1 \%$ ), of which half of them showed strong labeling intensity and another half showed a weak one (10 cases each, 28.6\%). Only one case showed evident Her-2 exnression (2.9\%). Most cases showed low mitotic activity as indicated by Ki-67 ( 24 cases, $68.6 \%$ ); while the rest showed high $\mathrm{Ki}$ 67 expression (11 cases, $31.4 \%$ ). The mean expression of $\mathrm{Ki}-67$ is $20.8 \% \pm \mathrm{SD} 22.1$, with median $12 \%$ and range $2 \%$ to $80 \%$. By summation of all previous results, molecular subtype was assumed as: Luminal A 19 cases (54.3\%), luminal B 7 cases ( $20.0 \%$ ) and triple negative 9 cases (25.7\%).

Leptin immunostain was positive in 21 cases out of the 35 studied mammary carcinoma cases ( $60 \%$ ) and negative in 14 cases (40\%). Moderate leptin staining intensity was noted in 9 cases ( $25.7 \%$ ); while strong staining intensity was noted in 12 cases $(34.3 \%)$. Five cases of peri-tumoral fibrocystic disease were studied; all showed leptin positivity in ductal cells.

Correlating leptin immunohistochemistry results with other findings, we found that significant relationship was found between leptin staining and mammary carcinoma histopathological type. Most invasive duct carcinoma (NST) showed positive leptin immunostaining (19/28 cases, 67.9\%). On the other hand, most cases of the other types (lobular and mixed carcinomas) showed negative staining (5/7 cases, $71.4 \%)$, with only two cases of lobular and papillary carcinomas showing moderate and strong leptin immunostaining respectively ( $p$ value 0.027 ).

Most cases with neoadjuvant chemotherapy were leptin-negative (3/4 cases, $75.0 \%)$ with insignificant $p$-value of 0.292 . Leptin immunostaing had no correlation to $\mathrm{T}$ stage; most cases of $\mathrm{T} 1$ were leptin-positive (4/7 cases, $57.1 \%$ ); while most cases of T2 were also leptin-positive (14/22 cases, $63.6 \%$ ). On contrary, most cases of $\mathrm{T} 3$ were leptinnegative (4/6 cases, $66.7 \%)$.

As regards cases with in situ component, leptin positivity was noted in 9/17 cases $(52.9 \%$ ) ( $p$-value of 0.625 ). Concentrating on leptin positivity inside the in situ carcinoma regions, we found that $8 / 12$ ( $66.7 \%$ ) showed leptin-positive anaplastic cells. It is worthy to say that the four leptin-negative in situ cellular regions were in mixed and invasive lobular carcinoma cases ( $p$-value 0.131).

The majority of studied carcinoma cases with tumor lymphovascular emboli were leptin-negative ( 6/9 cases, 66.7\%); also those with tumor perineural infiltration $(4 / 5,80.0 \%)$, with $p$-values 0.094 and 0 . 141 respectively.

As regarding tumor lymph nodal metastasis, most of cases without nodal metastasis (N0) were leptin-positive (13/17 cases, $76.5 \%$ ) with significant 
$p$-value of 0.025 . N1 showed equal proportion between leptin negativity and positivity (5/10 cases, $50.0 \%$ each), while all cases of N2 were leptinnegative (3/3 cases, $100.0 \%)$ and most of $\mathrm{N} 3$ cases were also leptin-negative (3/5 cases, $60.0 \%$ ).

The majority of grade-I was leptin-positive ( $8 / 10$ cases, $80.0 \%$ ), while leptin-positive cases in grade-II represent only $48.0 \%$ (12/25 cases) with more grade-II cases expressing leptin negativity ( $13 / 25$ cases, $52.0 \%$ ) ( $p$-value of 0.084 ).

A significant relationship was detected between leptin immunostaining and tumor staging with most cases exhibiting lower stages I and II express leptin positivity (18/27 cases, 66.7\%) and on contrary, the minority of cases exhibiting higher stage III express leptin positivity ( $2 / 8$ cases only, $25.0 \%)$ with $p$-value of 0.051 . Leptin positivity in stage IA was $(13 / 17$ cases, $76.5 \%)$, stage IB was $(4 / 5$ cases, $80.0 \%)$, stage II was (1/5 cases, $20.0 \%)$, stage IIIA was ( $1 / 1$ case, $100.0 \%)$, stage IIIB was ( $1 / 5$ cases, $20.0 \%)$ and none in stage IIIC $(0 / 2$ cases, $0 \%$ ).

Focusing on other immune markers and leptin, we found that estrogen-positive cases significantly correlate with leptin. Most estrogen-positive cases were leptin-positive (19/26 cases, $73.1 \%)$ with $p$ value of 0.0001 . Leptin positivity correlates also
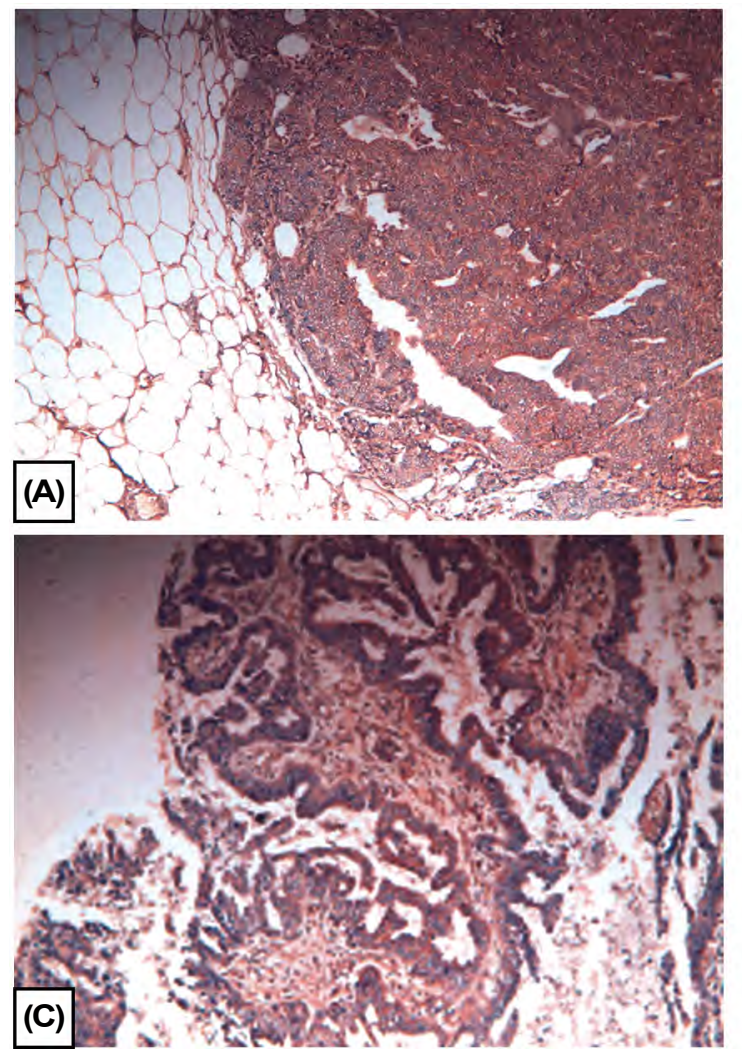

with estrogen intensity, being noted in 14/18 cases with strong estrogen expression (77.8\%), with $p$ value of 0.004 . This also was observed with progesterone positivity. Most progesterone-positive cases were leptin-positive (16/20 cases, $80.0 \%)$, with $p$-value of 0.002 . Progesterone intensity was also correlated with leptin, $9 / 10$ cases with strong progesterone expression were leptin-positive ( $90.0 \%$ ) with $p$-value of 0.004 . No significant relationship was found between Her-2 and leptin. It was noted that 19/34 cases of negative Her-2 cases were positive to leptin immune staining ( $55.9 \%$ ), and meanwhile the only case of positive Her-2 was positive to leptin (1/1 case, 100.0\%) ( $p$ value 1$)$.

As regards $\mathrm{Ki}-67$, most cases with high mitotic index were leptin-negative (7/11 cases, $63.6 \%)$; on the other side, most cases with low mitotic index were leptin-positive (16/24 cases, 66.7\%) but $p$-value was insignificant of 0.093 .

A significant correlation between leptin and molecular subtype was encountered ( $p$-value 0.016). Most cases of luminal A and luminal B types were leptin-positive (15/19 cases, $78.9 \%$ \& 4/7 cases, $57.1 \%$ respectively). On the contrary, most triple negative cases were leptin-negative (7/9 cases, $77.8 \%)$.
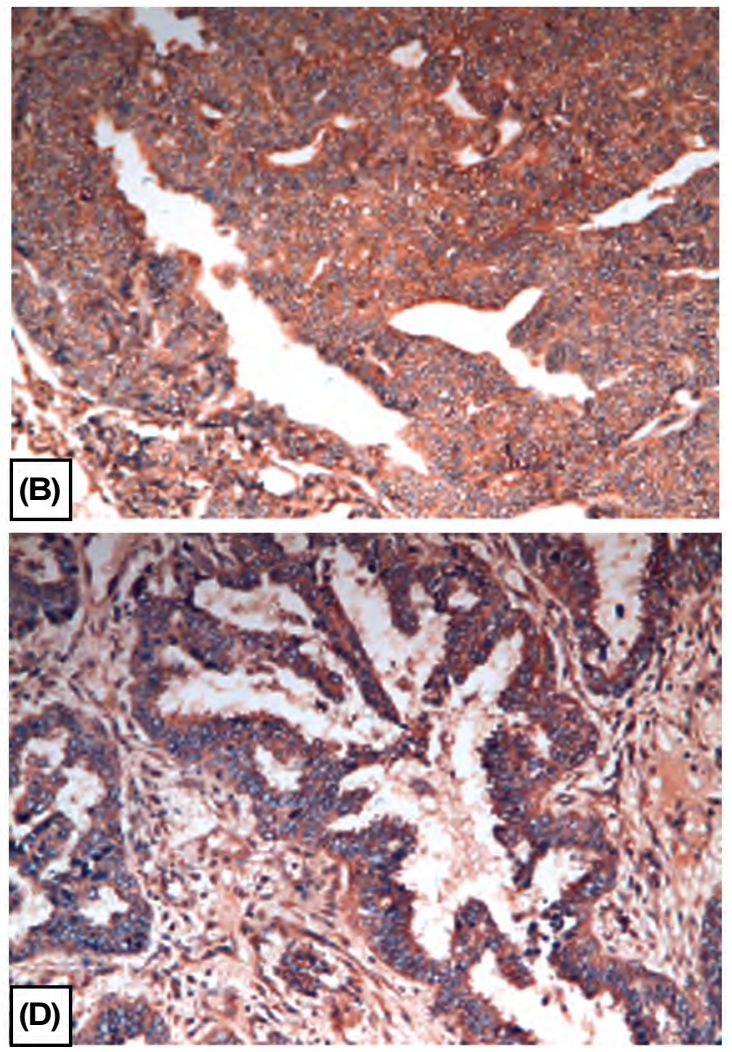

Fig. (1): Positive leptin strong and diffuse expression in mammary invasive carcinoma. (A \& B): Invasive duct carcinoma, (C \& D): Invasive papillary carcinoma (X100 \& X200, Leptin immune stain). 

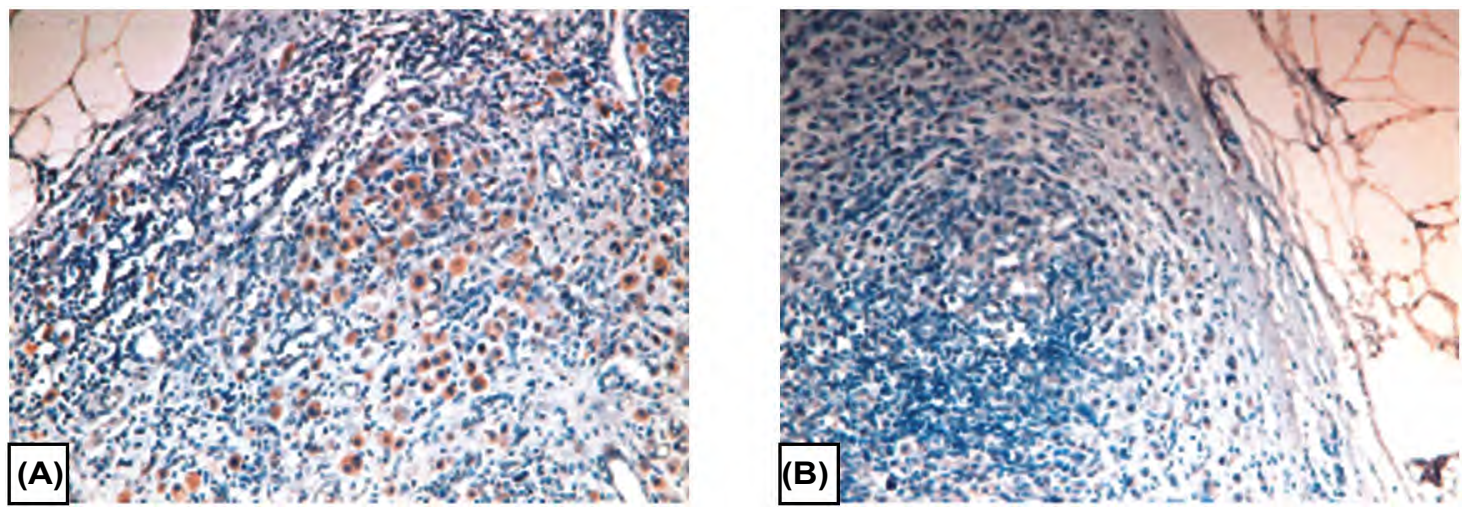

Fig. (2): (A) Positive leptin expression \& (B) Negative leptin expression in invasive lobular carcinoma (X100, Leptin immune stain).
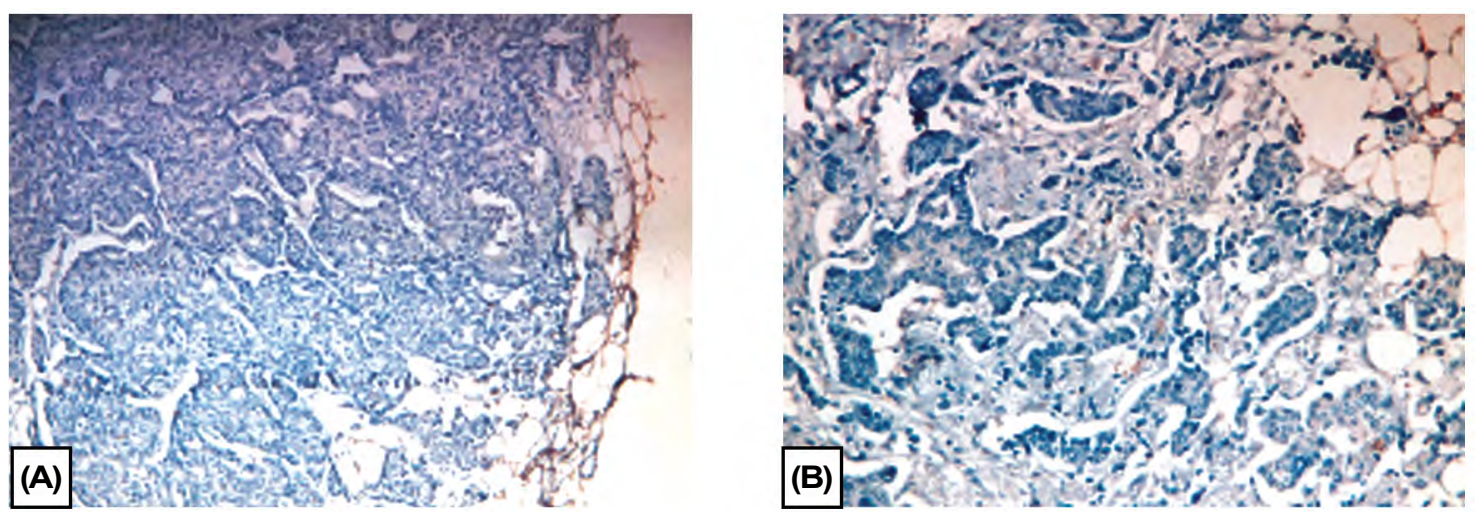

Fig. (3): Negative leptin expression in invasive duct carcinoma (X100 \& X200, Leptin immune stain)
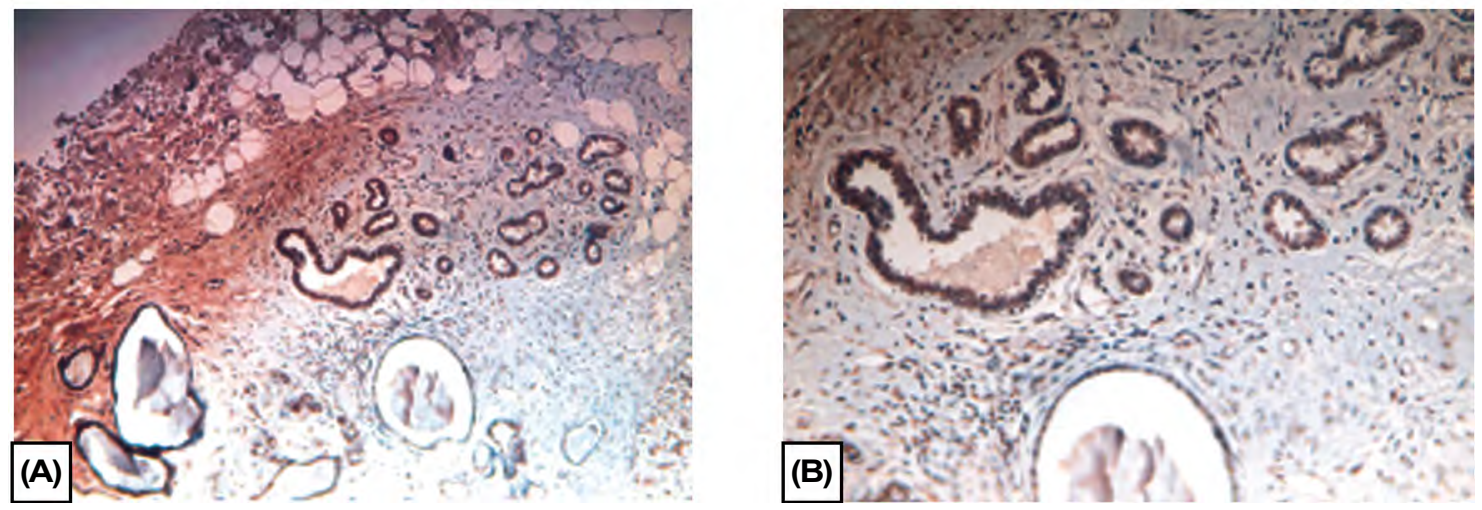

Fig. (4): Positive leptin expression in peri-tumoral fibrocystic disease (X100 \& X200, Leptin immune stain).
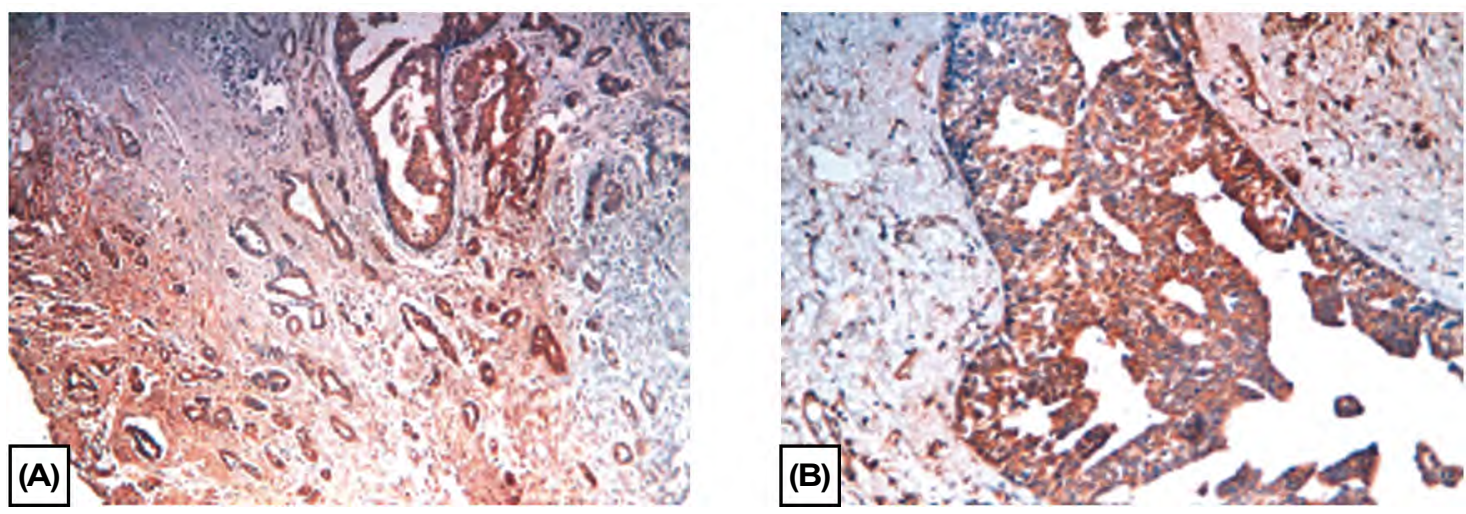

Fig. (5): Positive leptin expression as regards in situ duct carcinoma with surrounding invasive component (X100 \& X200, Leptin immune stain). 

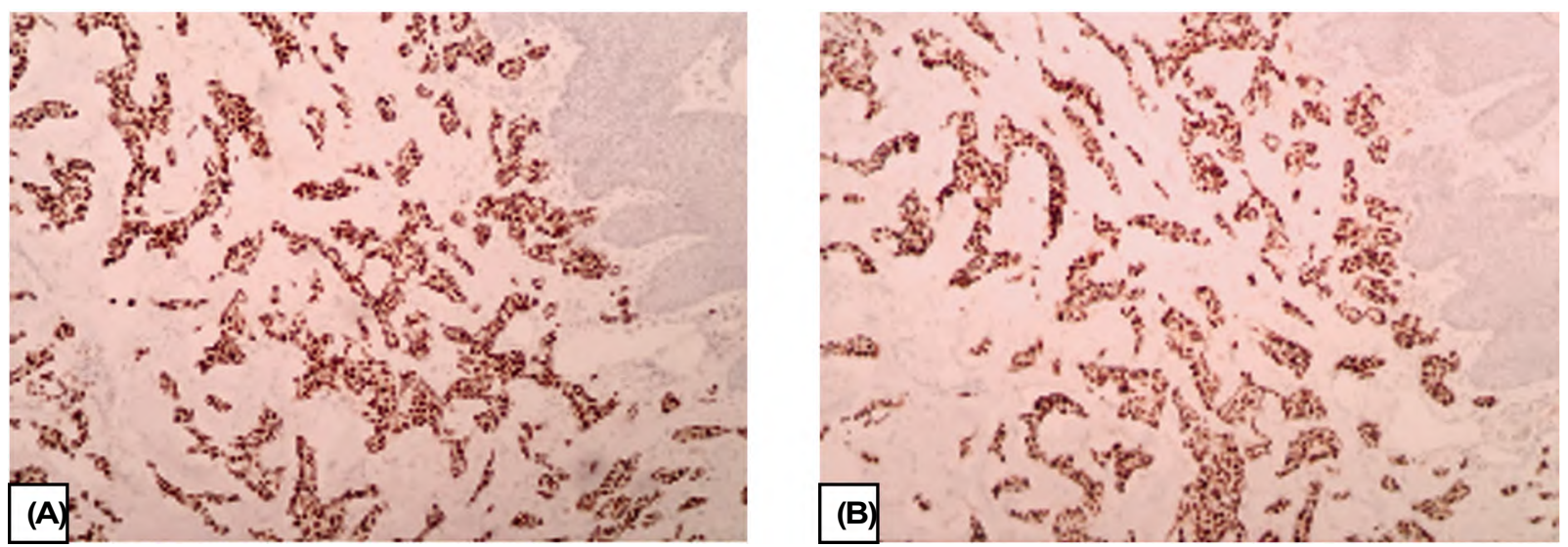

Fig. (6): Positive estrogen and progesterone expression in invasive duct carcinoma (X100, A- Estrogen, B- Progesterone immune stains).
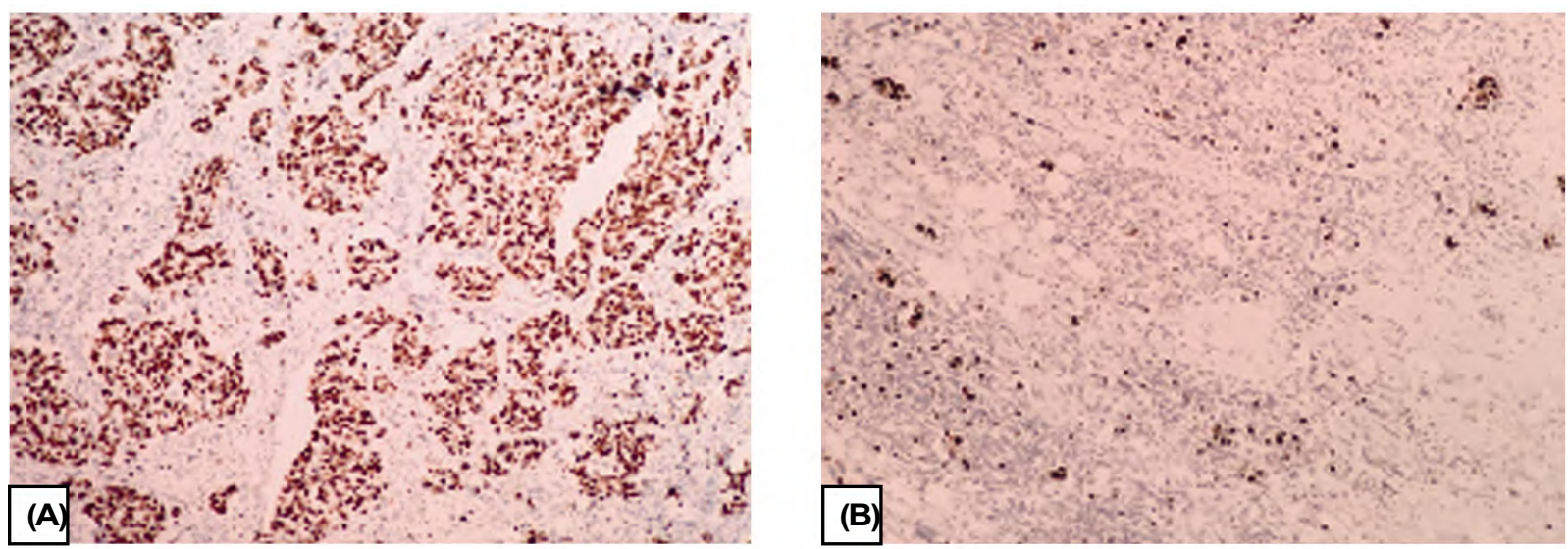

Fig. (7): Ki-67 high and low expressions in invasive duct carcinoma (X100, Ki-67 immune stain)
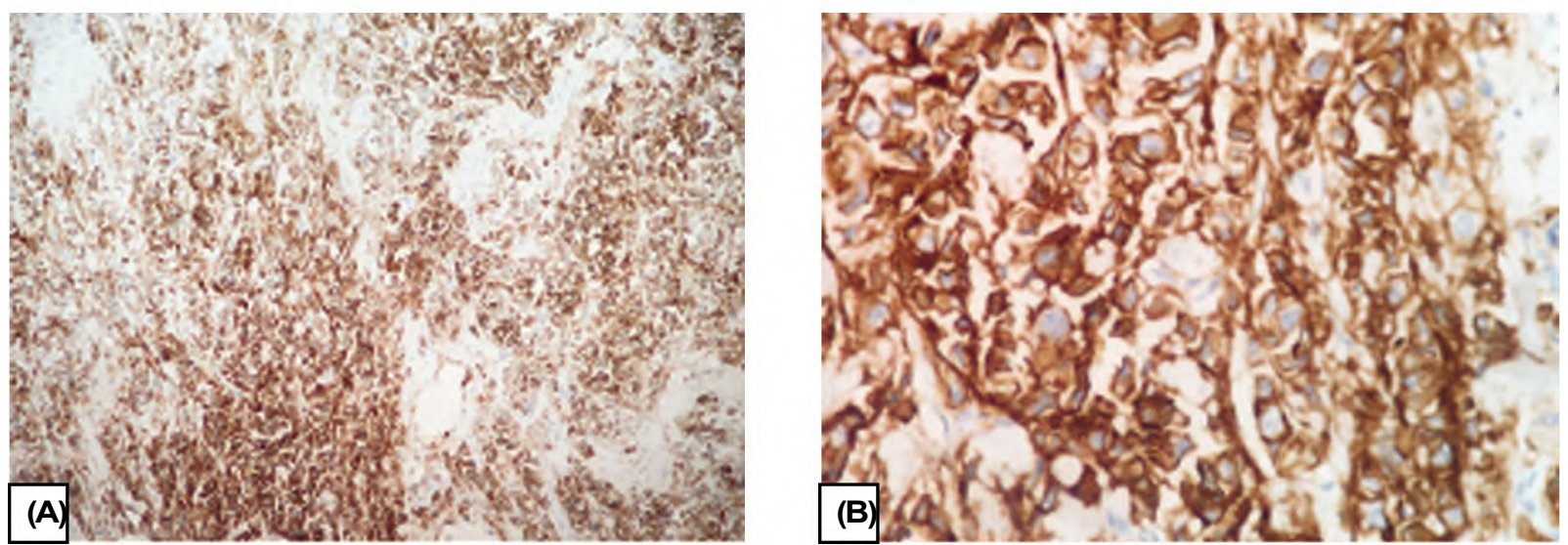

Fig. (8): Positive Her-2 expression in invasive duct carcinoma (X100 \& X200 Her-2 immune stain).

\section{Discussion}

Although breast cancer treatment has wide steps in progress, the 5-year relative survival for tumor can be less than $17 \%$. This may be due to early diagnosis retardation, large population with preliminary advanced-stage $\mathrm{BC}$, and failed treatment regimens in some types [63,64]. Therefore, it is lifesaving to identify new prognostic factors and therapeutic targets for breast carcinoma; in order to stratify patients, check tumor progression, and make early diagnosis feasible.

Leptin is a circulating satiety hormone which is produced primarily by white adipose tissue. It has a crucial role in regulating energy metabolism and cellular proliferation. Leptin can provoke leptin receptor, different signaling pathways, and enzyme aromatase. Aberrant expression of leptin is involved in pathogenesis of many carcinomas, even can be 
used in their differential diagnosis and prognosis [ 65]. It exerts its proliferative effects on malignant epithelial cells, which may activate carcinogenesis of breast tissue and promote the proliferation as well as angiogenesis of cancer cells [66-68].

In this study, we aimed to explore leptin relations in breast carcinoma with its different clinicopathologic parameters. Thirty-five female mammary carcinoma cases were studied. By keeping immnunohistochemical data together, molecular subtype was assumed as: Luminal A (54.3\%), luminal B (20.0\%) and triple negative $(25.7 \%)$. Leptin immunostain was positive in 21 cases out of the 35 studied mammary carcinoma cases $(60 \%)$ and negative in 14 cases (40\%). Moderate leptin staining intensity was noted in 9 cases $(25.7 \%)$; while strong staining intensity was noted in 12 cases $(34.3 \%)$. Five cases of peri-tumoral fibrocystic disease were studied; all showed leptin positivity in ductal cells.

Our study showed lower leptin-positive percentage of breast cancer than that found by Ishikawa et al., who found that overexpression of leptin, as determined by staining intensity, was observed in $92 \%$ of studied breast cancer cases but in no normal epithelium and also that distant metastasis occurred more frequently with the increasing expression of leptin. They postulated that leptin may have a promoting effect on the carcinogenesis and metastasis of breast cancer, possibly in an autocrine manner. Functional inhibition of leptin may be effective for the prevention and treatment of breast cancer [69]. Their higher detected percentage of breast cancer can be attributed to more number of exclusively studied invasive duct carcinoma cases and the semi-quantitative reading of immunostaining. Also Yongnam Kim et al., found that $84 \%$ of their studied carcinoma cases showed a leptin expression [70]. This is due to lone postmenopausal patients' study category.

Correlating leptin immunohistochemistry results with other findings, we found that significant relationship was found between leptin staining and mammary carcinoma histopathological type. Most invasive duct carcinoma (NST) showed positive leptin immunostaining (67.9\%). On the other hand, most cases of the other types showed negative staining (5/7 cases, $71.4 \%)$, with only two cases of lobular and papillary carcinomas showing moderate and strong leptin immunostaining respectively ( $p$-value 0.027).

Most cases with neoadjuvant chemotherapy were leptin-negative $(75.0 \%)$ with insignificant $p$ value of 0.292 . This is corresponding to Yongnam
Kim et al., who found insignificant relation between leptin and chemotherapeutic treatment [70]. Kong et al., also stated that positive expression of leptin was superior in the Pathological Complete Response (PCR) group to that in the progressive disease group ( $p=0.049, p=0.025$ ) [71]. On the other hand, Del Fabbro et al., reported overweight patients receiving neoadjuvant therapy had lower ( PCR) rates. Karatas et al., suggested leptin was an independent prognostic factor for the reduction of PCR to neoadjuvant chemotherapy in breast cancer patients. This can be attributed to their larger sample of patients receiving neoadjuvant treatment [72,73].

Leptin immunostaing had no correlation to $\mathrm{T}$ stage; most cases of $\mathrm{T} 1$ were leptin-positive ( $57.1 \%$ ); while most cases of $\mathrm{T} 2$ were also leptinpositive (14/22 cases, 63.6\%). On contrary, most cases of T3 were leptin-negative (4/6 cases, 66.7\%). This was similar to Khabaz et al., who also found no significant association of leptin immunostaining with tumor size [74]. As regards cases with in situ component, leptin positivity was noted in $(52.9 \%)$ ( $p$-value of 0.625). Concentrating on leptin positivity inside the in situ carcinoma regions, we found that $(66.7 \%)$ showed leptin-positive dysplastic cells. It is worthy to say that the four leptinnegative in situ cellular regions were in mixed and invasive lobular carcinoma cases ( $p$-value 0.131). All the cases with peri-tumoral fibrocystic disease showed leptin positivity in this region.

Leptin positivity was also evident in DCIS in previous studies. Caldefie-Chézet et al., declared that leptin was expressed in $50 \%$ of cases in DISC. Since leptin expression corresponded to $80 \%$ and $75 \%$ of the cases of IDC grades I and II, respectively, and was only revealed in $60 \%$ of the cases of IDC grade III studied. Leptin was expressed by all modified, benign or malignant breast cells and not only by breast cancer cells. It was expressed in the vicinity of a ductal breast lesion. This suggests that leptin may be a proliferative factor for the development of ductal breast cancer [75-77].

The majority of studied carcinoma cases with tumor lymphovascular emboli were leptin-negative ( $66.7 \%$ ); also those with tumor perineural infiltration $(80.0 \%$ ), with $p$-values 0.094 and 0.141 respectively. As regarding tumor lymph nodal metastasis, most of cases without nodal metastasis ( N0) were leptin-positive (76.5\%) with significant $p$-value of 0.025 . The majority of grade-I was leptin-positive (80.0\%), while leptin-positive cases in grade-II represent only $48.0 \%$ ( $p$-value of 0.084 ). A significant relationship was detected between 
leptin immunostaining and tumor staging with most cases exhibiting lower stages I and II express leptin positivity $(66.7 \%)$ and on contrary, the minority of cases exhibiting higher stage III express leptin positivity $(25.0 \%)$ with $p$-value of 0.051 . This was similar to Khabaz et al., who reported a considerable fraction of stage IIb and stage III were found to be common with low leptin immunostaining. Significantly, more cases with metastases in lymph nodes were observed in low score staining $(p=0.0300)$ [74]. This is contradicted with what Yongnam Kim et al., reported, as they found that disease stage was not different; according to the expression of leptin in the postmenopausal patients [70]. Again this can be attributed to their restricted postmenopausal patients study.

Estrogen-positive cases significantly correlate with leptin. Most estrogen-positive cases were leptin-positive $(73.1 \%)$ with $p$-value of 0.0001 . This also was observed with progesterone positivity. Most progesterone-positive cases were leptinpositive $(80.0 \%)$, with $p$-value of 0.002 . No significant relationship was found between Her-2 and leptin. It was noted that $(55.9 \%)$ of negative Her-2 cases were positive to leptin immune staining, and meanwhile the only case of positive Her-2 was positive to leptin (100.0\%) (p-value 1). As regards Ki-67, most cases with high mitotic index were leptin-negative $(63.6 \%)$; on the other side, most cases with low mitotic index were leptin-positive $(66.7 \%)$ but $p$-value was insignificant of 0.093. A significant correlation between leptin and molecular subtype was encountered ( $p$-value 0.003). Most cases of luminal A and luminal B types were leptinpositive (78.9\% \& $57.1 \%$ respectively). On the contrary, most triple negative cases were leptinnegative (77. $8 \%$ ).

This is in concordance to Yongnam Kim et al., as well as Khabaz et al., who stated that most HRpositive studied patients showed a leptin expression [ 70,74]. HER-2/neu expression, lymphatic invasion and histologic nuclear grade were not different according to the expression of leptin [70]. Our findings are different from previous studies that declared high leptin expression was significantly associated with high Ki-67 expression and triple negative breast carcinoma [76-78]. This can be related to more studied triple negative cases.

As deduced from all the above data, leptin is a conflicting topic in breast carcinoma. Still, studies with broader panel of cases and unified standardized way of immune markers assessment are certainly of great value for assessing the value of leptin immunostaining in mammarv carcinomas.

\section{Conclusions and Recommendations:}

Leptin immune stain is a helpful method in outlining the prognosis of breast carcinoma. Our study proposes that leptin could have a role in identifying the mammary carcinoma type, stage, grade and treatment in $\mathrm{BC}$, due to its association with many clinicopathological factors.

\section{References}

1- FERLAY J., COLOMBET M., SOERJOMATARAM, MATHERS C., PARKIN D.M., PIÑEROS M., et al.: Estimating the global cancer incidence and mortality in 2018: GLOBOCAN sources and methods. Int. J. Cancer, 144 (8): 1941-53, 2019.

2- DANAEI G., VANDER HOORN S., LOPEZ A.D., MURRAY C.J. and EZZATI M.: Comparative Risk Assessment Collaborating Group. Causes of cancer in the world: Comparative risk assessment of nine behavioural and environmental risk factors. Lancet, 366: 1784-93, 2005.

3- O'SULLIVAN C.C., LOPRINZI C.L. and HADDAD T.C.: Updates in the evaluation and management of breast cancer. Mayo Clin. Proc., 93: 794-807, 2018.

4- NCD Risk Factor Collaboration (NCD-RisC). Trends in adult body-mass index in 200 countries from 1975 to 2014: A pooled analysis of 1698 population-based measurement studies with 19.2 million participants. Lancet, 387: 1377-96, 2016.

5- PEARSON-STUTTARD J., ZHOU B., KONTIS V., BENTHAM J., GUNTER M.J. and EZZATI M.: Worldwide burden of cancer attributable to diabetes and high body-mass index: A comparative risk assessment. Lancet Diabetes Endocrinol, 6 (6): e6-e15, 2018.

6- SUNG H., SIEGEL R.L., TORRE L.A., PEARSONSTUTTARD J., ISLAMI F., FEDEWA S.A., et al.: Global patterns in excess body weight and the associated cancer burden. CA Cancer J. Clin., 69 (2): 88-112, 2019.

7- RENEHAN A.G., TYSON M., EGGER M., HELLER R.F. and ZWAHLEN M.: Body-mass index and incidence of cancer: A systematic review and meta-analysis of prospective observational studies. Lancet, 371: 569-78, 2008.

8- SUNG H., SIEGEL R.L., TORRE L.A., PEARSONSTUTTARD J., ISLAMI F., FEDEWA S.A., et al.: Global patterns in excess body weight and the associated cancer burden. CA Cancer J. Clin., 69 (2): 88-112, 2019.

9- CHAN D.S., VIEIRA A.R., AUNE D., BANDERA E.V., GREENWOOD D.C., McTIERNAN A., et al.: Body mass index and survival in women with breast cancer-systematic literature review and metaanalysis of 82 follow-up studies. Ann. Oncol., 25 (10): 1901-14, 2014

10- LAUDISIO D., MUSCOGIURI G., BARREA L., SAVASTANO S. and COLAO A.: Obesity and breast cancer in premenopausal women: Current evidence and future perspectives. Eur. J. Obstet. Gynecol. Reprod. Biol., 230: 217-21, 2018.

11- CHEN D.C., CHUNG Y.F., YEH Y.T., CHAUNG H.C., KUO F.C., FU O.Y., et al.: Serum adiponectin and leptin levels in Taiwanese breast cancer patients. Cancer Lett., 237: 109-14, 2006. 
12- GROSSMANN M.E., RAY A., DOGAN S., MIZUNO N.K. and CLEARY M.P.: Balance of adiponectin and leptin modulates breast cancer cell growth. Cell Res., 18: 1154-6, 2008.

13- KANG J.H., LEE Y.Y., YU B.Y., YANG B.S., CHO K.H., YOON D.K., et al.: Adiponectin induces growth arrest and apoptosis of MDA-MB-231 breast cancer cell. Arch. Pharm. Res., 28: 1263-9, 2005.

14- NAKAYAMA S., MIYOSHI Y., ISHIHARA H. and NOGUCHI S.: Growth-inhibitory effect of adiponectin via adiponectin receptor 1 on human breast cancer cells through inhibition of s-phase entry without inducing apoptosis. Breast Cancer Res. Treat., 112: 405-10, 2008.

15- WAUTERS M., CONSIDINE R.V. and VAN GAAL L.F.: Human leptin: From an adipocyte hormone to an endocrine mediator. Eur. J. Endocrinol., 143 (3): 293-311, 2000.

16- BONNET M., DELAVAUD C., LAUD K., GOURDOU I., LEROUX C., DJIANE J., et al.: Mammary leptin synthesis, milk leptin and their putative physiological roles. Reprod Nutr. Dev., 42 (5): 399-413, 2002.

17- BRANN D.W., WADE M.F., DHANDAPANI K.M., MAHESH V.B. and BUCHANAN C.D.: Leptin and reproduction. Steroids, 67 (2): 95-104, 2002.

18- NEVILLE M.C., McFADDEN T.B. and FORSYTH I.: Hormonal regulation of mammary differentiation and milk secretion. J. Mammary Gland. Biol. Neoplasia, 7 ( 1): 49-66, 2002.

19- GOUMENOU A.G., MATALLIOTAKIS I.M., KOUMANTAKIS G.E. and PANIDIS D.K.: The role of leptin in fertility. Eur. J. Obstet. Gynecol. Reprod Biol., 106 (2): 118-24, 2003.

20- SWEENEY G.: Leptin signalling. Cell Signal., 14 (8): 655-63, 2002.

21- ZABEAU L., LAVENS D., PEELMAN F., EYCKERMAN S., VANDEKERCKHOVE J. and TAVERNIER J.: The ins and outs of leptin receptor activation. FEBS Lett., 546 (1): 45-50, 2003.

22- GAROFALO C., KODA M., CASCIO S., SULKOWSKA M., KANCZUGA-KODA L., GOLASZEWSKA J., et al.: Increased expression of leptin and the leptin receptor as a marker of breast cancer progression: Possible role of obesity-related stimuli. Clin. Cancer Res., 12: 1447-53, 2006.

23- JARDÉ T., CALDEFIE-CHÉZET F., DAMEZ M., MISHELLANY F., PENAULT-LLORCA F., GUILLOT J., et al.: Leptin and leptin receptor involvement in cancer development: A study on human primary breast carcinoma. Oncol. Rep., 19: 905-11, 2008.

24- ARTAC M. and ALTUNDAG K.: Leptin and breast cancer: An overview. Medical Oncology, 29 (3): 1510-4, 2011.

25- DOYLE S.L., DONOHOE C.L., LYSAGHT J. and REYNOLDS J.V.: Visceral obesity, metabolic syndrome, insulin resistance and cancer. Proc. Nutr. Soc., 71: 181-9, 2012.

26- SOMA D., KITAYAMA J., YAMASHITA H., MIYATO H., ISHIKAWA M. and NAGAWA H.: Leptin augments proliferation of breast cancer cells via transactivation of HER2. J. Surg. Res., 149: 9-14, 2008.

27- ARTWOHL M., RODEN M., HOLZENBEIN T., FREUDENTHALER A., WALDHAUSL W. and BAUM-
GARTNER-PARZER S.M.: Modulation by leptin of proliferation and apoptosis in vascular endothelial cells. Int. J. Obes. Relat. Metab. Disord., 26 (4): 577-80, 2002.

28- WHITE A.J., NICHOLS H.B., BRADSHAW P.T. and SANDLER D.P.: Overall and central adiposity and breast cancer risk in the sister study. Cancer, 121: 3700-8, 2015.

29- ANDÒ S. and CATALANO S.: The multifactorial role of leptin in driving the breast cancer microenvironment. Nat. Rev. Endocrinol., 8: 263-75, 2011.

30- SAXENA N.K., VERTINO P.M., ANANIA F.A. and SHARMA D.: Leptin-induced growth stimulation of breast cancer cells involves recruitment of histone acetyltransferases and mediator complex to CYCLIN D1 promoter via activation of Stat3. J. Biol. Chem., 282: 13316-25, 2007.

31- REN H., ZHAO T., WANG X., GAO C., WANG J., YU M. and HAO J.: Leptin upregulates telomerase activity and transcription of human telomerase reverse transcriptase in MCF-7 breast cancer cells. Biochem. Biophys. Res. Commun., 394: 59-63, 2010.

32- WEI L., LI K., PANG X., GUO B., SU M., HUANG Y., et al.: Leptin promotes epithelial-mesenchymal transition of breast cancer via the upregulation of pyruvate kinase M2. J. Exp. Clin. Cancer Res., 35: 166, 2016.

33- PARK J.W., ZHAO L., WILLINGHAM M.C. and CHENG S. Y.: Inhibition of STAT3 signaling blocks obesity-induced mammary hyperplasia in a mouse model. Am. J. Cancer Res., 7: 727-39, 2017.

34- HUANG Y., JIN Q., SU M., JI F., WANG N., ZHONG C., et al.: Leptin promotes the migration and invasion of breast cancer cells by upregulating ACAT2. Cell Oncol., 40: 537-47, 2017.

35- WANG L., TANG C., CAO H., LI K., PANG X., ZHONG L., et al.: Activation of IL-8 via PI3K/Akt-dependent pathway is involved in leptin-mediated epithelialmesenchymal transition in human breast cancer cells. Cancer Biol. Ther., 16: 1220-30, 2015.

36- ZAHID H., SUBBARAMAIAH K., IYENGAR N.M., ZHOU X.K., CHEN I.C., BHARDWAJ P., et al.: Leptin regulation of the p53-HIF1 $\alpha /$ PKM2-aromatase axis in breast adipose stromal cells-a novel mechanism for the obesity-breast cancer link. Int. J. Obes., 42: 711-20, 2017.

37- CATALANO S., MAURO L., MARSICO S., GIORDANO C., RIZZA P., RAGO V., et al.: Leptin induces, via ERK1/ERK2 signal, functional activation of estrogen receptor alpha in MCF-7 cells. J. Biol. Chem., 279: 19908$15,2004$.

38- KHANAL T., KIM H.G., DO M.T., CHOI J.H., WON S.S., KANG W., et al.: Leptin induces CYP1B1 expression in MCF-7 cells through ligand-independent activation of the ERa pathway. Toxicol. Appl. Pharmacol., 277: 39- 48, 2014.

39- SAXENA N.K., TALIAFERRO-SMITH L., KNIGHT B.B., MERLIN D., ANANIA F.A., O'REGAN R.M., et al.: Bidirectional crosstalk between leptin and insulinlike growth factor-I signaling promotes invasion and migration of breast cancer cells via transactivation of enidermal ornuxth factor recentor Cancer Res 68. 071?. 
40- CHA Y., KANG Y. and MOON A.: HER2 induces expression of leptin in human breast epithelial cells. BMB Rep., 45: 719-23, 2012.

41- FEOLA A., RICCI S., KOUIDHI S., RIZZO A., PENON A., FORMISANO P., et al.: Multifaceted breast cancer: The molecular connection with obesity. J. Cell Physiol., 232: 69-77, 2017.

42- GIORDANO C., VIZZA D., PANZA S., BARONE I., BONOFIGLIO D., LANZINO M., et al.: Leptin increases HER2 protein levels through a STAT3-mediated upregulation of Hsp90 in breast cancer cells. Mol. Oncol., 7: 379-91, 2013.

43- AMBROSINI G., NATH A.K., SIERRA-HONIGMANN M.R. and FLORES-RIVEROS J.: Transcriptional activation of the human leptin gene in response to hypoxia. Involvement of hypoxia-inducible factor 1. J. Biol. Chem., 277 (37): 34601-9, 2002.

44- GROSFELD A., ANDRE J., HAUGUEL-De MOUZON S., BERRA E., POUYSSEGUR J. and GUERRE-MILLO M.: Hypoxia-inducible factor 1 transactivates the human leptin gene promoter. J. Biol. Chem., 277 (45): 42953-7, 2002.

45- CAO R., BRAKENHIELM E., WAHLESTEDT C., THYBERG J. and CAO Y.: Leptin induces vascular permeability and synergistically stimulates angiogenesis with FGF-2 and VEGF. Proc. Natl. Acad. Sci. USA, 98 (11): 6390-5, 2001.

46- PARK H.Y., KWON H.M., LIM H.J., HONG B.K., LEE J. Y., PARK B.E., et al.: Potential role of leptin in angiogenesis: Leptin induces endothelial cell proliferation and expression of matrix metalloproteinases in vivo and in vitro. Exp. Mol. Med., 33 (2): 95-102, 2001.

47- KUME K., SATOMURA K., NISHISHO S., KITAOKA E., YAMANOUCHI K., TOBIUME S., et al.: Potential role of leptin in endochondral ossification. J. Histochem. Cytochem., 50 (2): 159-69, 2002.

48- IYENGAR N.M., GUCALP A., DANNENBERG A.J. and HUDIS C.A.: Obesity and cancer mechanisms: Tumor microenvironment and inflammation. J. Clin. Oncol., 34: 4270-6, 2016.

49- ROSE D.P. and VONA-DAVIS L.: Biochemical and molecular mechanisms for the association between obesity, chronic inflammation, and breast cancer. Biofactors, 40: $1-12,2014$

50- CRESPI E., BOTTAI G. and SANTARPIA L.: Role of inflammation in obesity-related breast cancer. Curr. Opin. Pharmacol., 1: 114-22, 2016.

51- PARK J., MORLEY T.S., KIM M., CLEGG D.J. and SCHERER P.E.: Obesity and cancer-mechanisms underlying tumour progression and recurrence. Nat. Rev. Endocrinol., 10: 455-65, 2014.

52- IYENGAR N.M., ZHOU X.K., GUCALP A., MORRIS P.G., HOWE L.R., GIRI D.D., et al.: Systemic correlates of white adipose tissue inflammation in earlystage breast cancer. Clin. Cancer Res., 22: 2283-9, 2016.

53- FELDMAN D.E., CHEN C., PUNJ V., TSUKAMOTO H. and MACHIDA K.: Pluripotency factor-mediated expression of the leptin receptor (OB-R) links obesity to oncogenesis through tumor-initiating stem cells. Proc. Natl. Acad. Sci. USA, 109: 829-34, 2012.
54- GUO S. and GONZALEZ-PEREZ R.R.: Notch, IL-1 and Leptin crosstalk outcome (NILCO) is critical for leptininduced proliferation, migration and VEGF/VEGFR-2 expression in breast cancer. PLoS ONE, 6: e21467, 2011.

55- ZHOU J., WULFKUHLE J., ZHANG H., GU P., YANG Y., DENG J., et al.: Activation of the PTEN/mTOR/STAT3 pathway in breast cancer stem-like cells is required for viability and maintenance. Proc. Natl. Acad. Sci. USA, 104: 16158-63, 2007.

56- GUO S., LIU M., WANG G., TORROELLA-KOURI M. and GONZALEZ-PEREZ R.R.: Oncogenic role and therapeutic target of leptin signaling in breast cancer and cancer stem cells. Biochim. Biophys. Acta., 1825: 207$22,2012$.

57- WANG T., FAHRMANN J.F., LEE H., LI Y.J., TRIPATHI S. C., YUE C., et al.: JAK/STAT3-regulated fatty acid oxidation is critical for breast cancer stem cell self-renewal and chemoresistance. Cell Metab., 27: 136-50, 2017.

58- RAY A.: Adipokine leptin in obesity-related pathology of breast cancer. J. Biosci., 37: 289-94, 2012.

59- GAROFALO C., KODA M., CASCIO S., SULKOWSKA M., KANCZUGA-KODA L., GOLASZEWSKA J., et al.: Increased expression of leptin and the leptin receptor as a marker of breast cancer progression: Possible role of obesity-related stimuli. Clin. Cancer Res., 12: 1447-53, 2006.

60- BLOOM H.J. and RICHARDSON W.W.: Histological grading and prognosis in breast cancer. A study of 1049 cases of which 359 have been followed for 15 years. Br.J. Cancer, 11: 359-77, 1957.

61- HORTOBAGYI G.N., CONNOLLY J.L., D'ORSI C.J., EDGE S.B., MITTENDORF E.A., RUGO H.S., et al.: AJCC cancer staging manual. Part XI Breast, (8): 589636, 2018

62- YUAN L., LI X. and WEI F.: Expression and clinical significance of Leptin and NF-kBp65 in cervical intraepithelial neoplasia. Chinese Journal of Oncology Prevention \& Treatment, 2015.

63- FERLAY J., SOERJOMATARAM I., DIKSHIT R., ESER S., MATHERS C., RABELO M., et al.: Cancer incidence and mortality worldwide: Sources, methods and major patterns in GLOBOCAN 2012. Int. J. Cancer, 136: E35986,2015

64- KERAMATINIA A., MOUSAVI-JARRAHI S.H., HITEH M. and MOSAVI-JARRAHI A.: Trends in incidence of breast cancer among women under 40 in Asia. Asian. Pac.J. Cancer Prev., 15: 1387-90, 2014.

65- ELESAWY Y.F., AMER S.I. and EESA A.N.: The reliability of leptin immunostain use for differentiating renal oncocytoma and chromophobe renal cell carcinoma. Kasr Al Ainy Med. J., 26: 5-13, 2020.

66- HAN C.Z., DU L.L., JING J.X., PARK Y.L. and BAE W.G.: Associations among lipids, leptin, and leptin receptor gene Gin223Arg polymorphisms and breast cancer in China. Biol. Trace. Elem. Res., 126: 38-48, 2008.

67- KHAN S., SHUKLA S., SINHA S. and MEERAN S.M.: Role of adipokines and cytokines in obesity-associated breast cancer: Therapeutic targets. Cytokine Growth Factor $n \quad n$ - n in nnd 
68- LAUD K., GOURDOU I., PESSEMESSE L., PEYRAT J.P. and DJIANE J.: Identification of leptin receptors in human breast cancer: Functional activity in the T47-D breast cancer cell line. Mol. Cell Endocrinol., 188: 21926, 2002

69- ISHIKAWA M., KITAYAMA J. and NAGAWA H.: Enhanced expression of leptin and leptin receptor (OB$\mathrm{R}$ ) in human breast cancer. Clin. Cancer Res., 10: 432531, 2004.

70- KIM Y., KIM S.Y., LEE J.J., SEO J., KIM Y.W., KOH S.H., et al.: Effects of the Expression of Leptin and Leptin Receptor (OBR) on the Prognosis of Early-stage Breast Cancers. Cancer Research and Treatment, 38 (3): 126, 2006.

71- KONG Y., DONG Q., JI H., SANG M., DING Y., ZHAO M., et al.: The Effect of the Leptin and Leptin Receptor Expression on the Efficacy of Neoadjuvant Chemotherapy in Breast Cancer. Med. Sci. Monit., 25: 3005-13, 2019.

72- KARATAS F., ERDEM G.U., SAHIN S., AYTEKIN A., YUCE D., SEVER A.R., et al.: Obesity is an independent prognostic factor of decreased pathological complete response to neoadjuvant che-motherapy in breast cancer patients. Breast, 32: 237-44, 2016.

73- EGIDIO D.F., HENRIQUE P., WARNEKE C.L., PULIVARTHI $K$ IITTON I K DFV $R$ ef al The ship between body composition and response to neoadjuvant chemotherapy in women with operable breast cancer. Oncologist, 17: 1240-45, 2012.

74- KHABAZ M.N., ABDELRAHMAN A., BUTT N., DAMNHORY L., ELSHAL M., ALDAHLAWI A.M., et al.: Immunohistochemical staining of leptin is associated with grade, stage, lymph node involvement, recurrence, and hormone receptor phenotypes in breast cancer. BMC Women's Health, 17: 105, 2017.

75- CALDEFIE-CHÉZET F., DAMEZ M., De LATOUR M. and VASSON M.P. LEPTIN: A proliferative factor for breast cancer? Study on human ductal carcinoma. Biochemical and Biophysical Research Communications, 334: 737-74, 2005.

76- JEONG Y.J., BONG J.G., PARK S.H., CHOI J.H. and OH H.K.: Expression of leptin, leptin receptor, adiponectin, and adiponectin receptor in ductal carcinoma in situ and invasive breast cancer. J. Breast Cancer, 14 (2): 96-103, 2011.

77- COLBERT L.S., WILSON K., KIM S., LIU Y., OPREAILIES G., GILLESPIE C., et al.: NILCO biomarkers in breast cancer from Chinese patients. BMC Cancer, 14: 249, 2014.

78- KIM H.S.: Leptin and Leptin Receptor Expression in Breast Cancer. Cancer Res. Treat., 41 (3): 155-63, 2009.

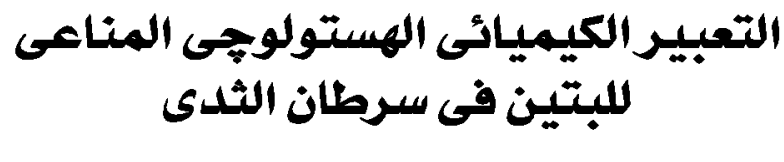

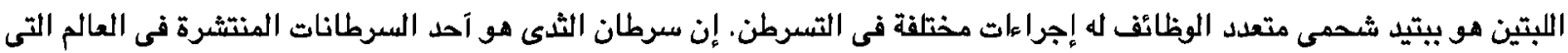

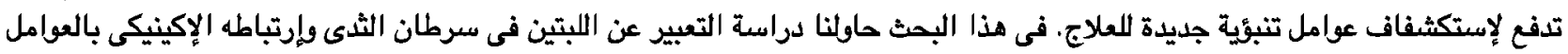

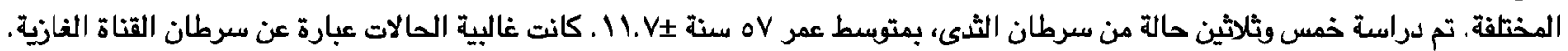

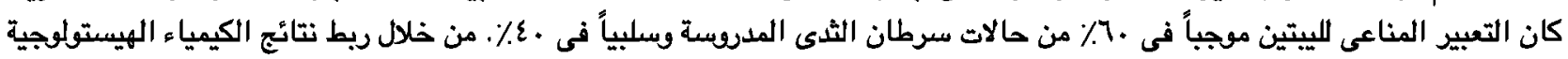

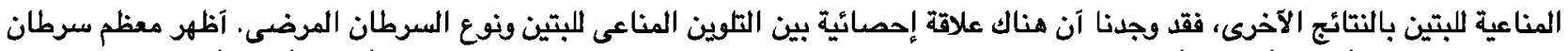

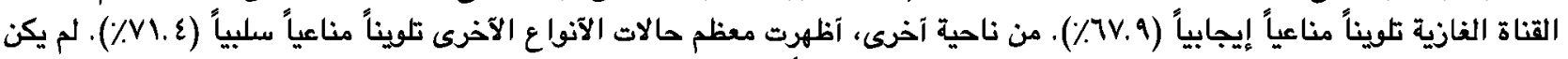

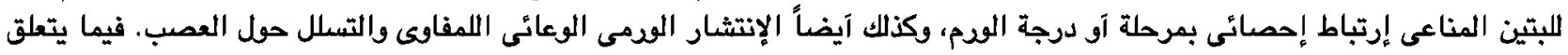

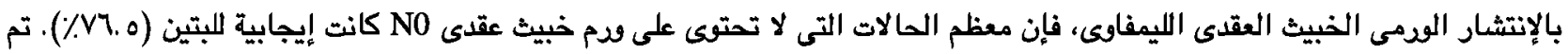

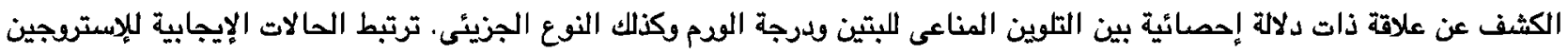

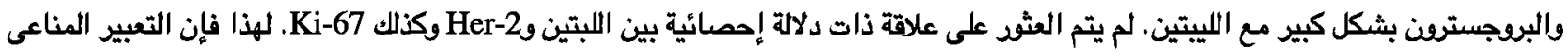

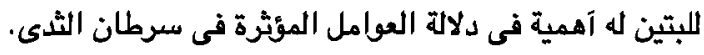

